\title{
AKUNTABILITAS DAN TRANSPARANSI PENGELOLAAN DANA ALOKASI DESA DI DESA PAO-PAO KECAMATAN TANETE RILAU KABUPATEN BARRU

\author{
Zulfan Nahruddin ${ }^{1}$ \\ ${ }_{1}^{1}$ Program Studi Ilmu Pemerintahan Fakultas Ilmu Sosial dan Ilmu Politik \\ Universitas Muhammadiyah Makassar \\ Jl. Sultan Alauddin No. 259 Makassar 90221 \\ Telp. 0411-866972 ext.107.Fax.0411-8655888 \\ zulfannahruddin@gmail.com
}

\begin{abstract}
The purpose of this study to determine accountability and transparency in the management of the allocation of funds in the village of Pao - Pao village Tanete Rilau Barru Subdistrict. This study uses quantitative methods. The results showed that the accountability of the management of allocated funds performing well overall dimensions, including the dimension of transparency that shows the management of funds allocated to Village Walk trasparan this happens because the information is easily accessible and good communication by village so pengengelolaan allocations village to be transparent, The same thing happened on the dimensions reabiliy, responsibility and responsiveness going well but on the dimension control is still categorized as good enough and need to be optimized to support accountability in the management of funds of the village.
\end{abstract}

Keywords : Accountability, transparency, management of village fund

\begin{abstract}
ABSTRAK
Tujuan penelitian ini untuk mengetahui akuntabilitas dan transparansi dalam pengelolaan dana alokasi desa di Desa Pao-Pao Kecamatan Tanete Rilau Kabupaten Barru. Penelitian ini menggunakan metode kuantitatif. Hasil penelitian menunjukkan bahwa akuntabilitas pengelolaan dana alokasi berjalan dengan baik dari keseluruhan dimensi, termasuk dalam dimensi transparansi yang menunjukkan pengelolaan dana alokasi desa berjalan trasparan hal ini terjadi karena adanya informasi yang mudah diakses serta komunikasi yang baik oleh perangkat desa sehingga pengengelolaan dana alokasi desa dianggap transparan. Hal yang sama terjadi pada dimensi reabiliy, responsibilitas dan responsivitas berjalan dengan baik tetapi pada dimensi control masih termasuk kategori cukup baik dan perlu dioptimalkan untuk menunjang akuntabilitas pengelolaan dana desa.
\end{abstract}

Kata Kunci : Akuntabilitas, transparansi, pengelolaan dana desa 


\section{A. LATAR BELAKANG}

Keberadaaan akuntabilitas begitu vital terhadap terciptanya penyelenggaraan pemerintahan yang baik, demokratis dan amanah. Kelembagaan pemerintahan yang berakuntabilitas publik berarti lembaga tersebut senantiasa dapat mempertanggungjawabkan segala kegiatan yang diamanatkan kepada lembaga tesebut Peran masyarakat penting dalam melakukan kontrol terhadap lembaga atau institusi yang diberikan amanah oleh rakyat untuk menyelenggarakan pembangunan dan pengelolaan anggaran sebagaimana yang diamanatkan undang-undang. Akuntabiltas dapat diformalkan melalui Undang-Undang, aturan, peraturan, dan pemerintah pengadilan atau didasarkan pada sejumlah pemeriksaan dan keseimbangan informal yang dikembangkan melalui konotasi langsung, rumor dukungan, ancaman oposisi atau tipe rumusan lain yang dipahami namun tak tertulis (Manggaukang, 2006).

Sementara transparansi merupakan suatu kebebasan untuk mengakses aktivitas politik dan ekonomi pemerintah dan keputusankeputusannya. Transparansi memungkin semua stakeholders dapat melihat struktur dan fungsi pemerintahan, tujuan dari kebijakan dan proyeksi fiskalnya, serta laporan (pertanggungjawaban) periode yang lalu. Akuntabilitas mengandung arti pertanggungjawaban, baik oleh orang-orang maupun badanbadan yang dipilih, atas pilihan-pilihan dan tindakan-tindakannya. Konsep keadilan berarti bahwa masyarakat diperlakukan secara sama di bawah hukum, dan mempunyai derajat yang sama dalam partisipasi politik dalam pemerintahannya.

Transparansi, akuntabilitas dan keadilan merupakan atribut yang terpisah. Akan tetapi, dua istilah yang pertama adalah tidak independen, sebab pelaksanaan akuntabilitas memerlukan transparansi (Shende dan Bennett, 2004).

Akuntabilitas dan trasparansi diperlukan dan penting untuk dipahami. Mengingat dalam pengelolaan Dana Desa (ADD) dilaksanakan dengan menggunakan prinsip hemat, terarah dan terkendali. Jenis kegiatan yang akan dibiayai melalui Alokasi Dana Desa (ADD), penting untuk dapat meningkatkan sarana pelayanan masyarakat berupa pemenuhan kebutuhan dasar desa, Selain itu Penguatan Kelembagaan Desa dan kegiatan lainnya yang bermanfaat untuk masyarakat desa. Mengingat desa merupakan suatu wilayah yang memiliki batas-batas tertentu yang ditempati oleh sejumlah orang yang disebut masyarakat yang memiliki satu kesatuan dan adat istiadat yang hidup saling mengenal dan bergotong-royong. masyarakat desa sebagian besar mencari nafkah dengan bekerja sebagai petani atau nelayan untuk memenuhi kebutuhan hidupnya. Dari pemahaman tersebut maka otonomi yang diamanat pada desa merupakan otonomi memunculkan kebutuhan berdasarkan asalusul dan adat istiadat Desa tersebut. Dapat pula diartikan bahwa otonomi desa bukan merupakan akibat dari peraturan perundangundangan, melainkan berasal dari asal-usul dan adat istiadat desa yang dikembangkan, dipelihara, dan digunakan oleh masyarakat desa.

Pada Undang-undang No. 6 Tentang Desa 2014, dijelaskan bahwa desa merupakan sebuah kesatuan masyarakat hukum yang memiliki batas-batas wilayah yang berwenang untuk mengatur dan mengurus kepentingan masyarakat setempat, berdasarkan asal-usul dan adat istiadat setempat yang diakui dan dihormati dalam sistem pemerintahan Negara Republik Indonesia. Untuk mengatur dan mengurus kepentingan masyarakat yang bertempat tinggal di desa diperlukan pendapatan desa agar tujuan pembangunan desa dan desa membangun tercapai. Salah satu sumber pendapatan desa yang diatur dalam Undang-Undang Desa adalah Alokasi Dana Desa (ADD). Alokasi Dana Desa (ADD) merupakan bagian dari dana perimbangan yang diterima pemerintah daerah kabupaten/kota paling sedikit $10 \%$ setelah dikurangin Dana Alokasi Khusus (DAK). Dari sisi ini peneliti anggap perlu untuk mengakaji pengelolaan dana alokasi desa dengan menitik beratkan pada akuntabilitas dan transparansi pengelolaan dana alokasi desa di Desa Pao-Pao Kecamatan Tanete Rilau Kabupaten Barru. 


\section{B. KONSEP AKUNTABILITAS}

Akuntabilitas merupakan suatu evoluasi kegiatan yang dilaksanakan oleh seorang petugas baik masih berada pada jalur otoritasnya atau sudah berada jauh di luar tanggungjawab dan kewenangannya. Dengan demikian, dalam setiap tingkah lakunya seorang pejabat pemerintah mutlak harus selalu memperhatikan lingkungan. Ada 4 (empat) dimensi yang membedakan akuntabilitas dengan yang lain, yaitu siapa yang harus melaksanakan akuntabilitas; kepada siapa dia berakuntabilitas; apa standar yang digunakan untuk penilaian akuntabilitasnya; dan nilai akuntabilitas itu sendiri. Carino (dalam Sedarmayanti, 2009)

\section{Menurut Koppell} mengajukan lima dimensi akuntabilitas. Kelima dimensi tersebut adalah transparansi, liabilitas, kontrol, responsibilitas, dan responsivitas. Kelima kategori tersebut tidaklah mutually exclusive, yaitu organisasi bisa saja akuntabel dilihat dari beberapa pandangan. Meski demikian, transparansi dan liabilitas dipandang mendasari konsep akuntabilitas dalam segala bentuk manifestasinya.

Rakhmat (2009) menyimpulkan bahwa akuntabilitas sebagai kewajiban seseorang atau unit organisasi untuk mempertanggungjawabkan pengelolaan dan pengendalian sumber daya dan pelaksanaan kebijakan yang dipercayakan kepadanya dalam rangka pencapaian tujuan yang telah ditetapkan.Selanjutnya dijelaskan bahwa Sumber kontrol internal bertolak pada kewenangan yang melekat pada hubungan formal secara hirarki atau hubungan sosial informal dengan agen publik. Sumber control eksternal suatu pemisahan yang serupa, dimana kewenangan mereka dapat dibedakan dalam dalam kewenangan yang berasal dari serangkaian peraturan atau pelaksanaan kekuasaan secara informal oleh kepentingan yang berasal di luar agen publik. Derajat kontrol yang tinggi mencerminkan kemampuan kontroler untuk menentukan tindakan dan kedalam tindakan dimana agen publik dan anggotanya dapat melakukannya. Sebaliknya derajat kontrol yang rendah memberikan deskresi pada bagian operasi agen publik.

\section{KONSEP TRANSPARANSI}

Transparansi mengisyaratkan bahwa laporan tahunan tidak hanya dibuat tetapi juga terbuka dan dapat diakses oleh masyarakat, karena aktivitas pemerintah adalah dalam rangka menjalankan amanat rakyat. Sekarang ini, banyak negara mengklasifikasikan catatan atau laporan sebagai Top Secret, Secret, Confidential dan Restricted, dan Official Secrets Acts membuat unauthorized disclosure terhadap suatu criminal offence. Kultur secara umum di banyak negara, baik negara maju maupun negara berkembang, adalah kerahasian (Shende dan Bennet, 2004). Tanpa adanya keterbukaan dan pelibatan publik sebagai suatu jejaring dalam pengambilan keputusan, pengambilan kebijakan di daerah hanya akan mengarah pada pemerintahan yang cenderung korup dan lemah dari sisi akuntabilitas.

Prinsip yang menjamin akses atau kebebasan bagi setiap orang untuk memperoleh informasi tentang penyelenggaraan pemerintahan, yakni informasi mengenai kebijakan,proses pembuatan, pelaksanaan, dan hasil yang dicapai. Menurut (Krina, 2003) prinsip ini menekankan kepada 2 aspek yakni komunikasi publik oleh pemerintah dan hak masyarakat terhadap akses informasi. Menurut (Krina, 2003) indikator-indikator dari transparansi adalah sebagai berikut : (1)Penyediaan informasi yang jelas tentang tanggung jawab (2) menyusun suatu mekanisme pengaduan jika ada peraturan yang dilanggar atau permintaan untuk membayar uang suap (3) Kemudahan akses informasi. (4) Meningkatkan arus informasi melalui kerjasama dengan media massa dan lembaga non pemerintah

Transparansi dan akuntabilitas dalam penyusunan anggaran, penetapan anggaran, perubahan anggaran dan perhitungan anggaran merupakan wujud pertanggungjawaban pemerintah daerah kepada masyarakat, maka dalam proses pengembangan wacana publik di daerah sebagai salah satu instrumen kontrol pengelolaan anggaran daerah, perlu diberikan 
Vol. IV No. 2 Oktober 2014

keleluasaan masyarakat untuk mengakses informasi tentang kinerja dan akuntabilitas anggaran. Oleh karena itu, anggaran daerah harus mampu memberikan informasi yang lengkap, akurat dan tepat waktu untuk kepentingan masyarakat, pemerintah daerah dan pemerintah pusat, dalam format yang akomodatif dalam kaitannya dengan pengawasan dan pengendalian anggaran daerah. Sejalan dengan hal tersebut, maka perencanaan, pelaksanaan dan pelaporan proyek dan kegiatan harus dilaksanakan secara terbuka dan dapat dipertanggungjawabkan secara teknis maupun ekonomis kepada pihak legislatif, masyarakat maupun pihak-pihak yang bersifat independen yang memerlukan.

\section{PENGELOLAAN DANA ALOKASI DESA}

Pengelolaan Keuangan Alokasi Dana Desa (ADD) merupakan bagian yang tidak terpisahkan dari Pengelolaan Keuangan Desa dalam APB Desa oleh karena itu dalam Pengelolaan Keuangan Alokasi Dana Desa (ADD) harus memenuhi Prinsip Pengelolaan Alokasi Dana Desa yaitu Seluruh kegiatan yang didanai oleh Alokasi Dana Desa (ADD) direncanakan, dilaksanakan dan dievaluasi secara terbuka dengan prinsip dari, oleh dan untuk masyarakat, Seluruh kegiatan harus dapat dipertanggungjawabkan

secara administrative, teknis dan hokum, Alokasi Dana Desa (ADD) dilaksanakan dengan menggunakan prinsip hemat, terarah dan terkendali., Jenis kegiatan yang akan dibiayai melalui Alokasi Dana Desa (ADD), sengat terbuka untuk meningkatkan sarana Pelayanan Masyarakat berupa Pemenuhan Kebutuhan Dasar, Penguatan Kelembagaan Desa dan kegiatan lainnya yang dibutuhkan Masyarakat Desa yang diputuskan melalui Musyawarah Desa dan Alokasi Dana Desa (ADD) harus dicatat dalam Anggaran Pendapatan dan Belanja Desa (APBDesa) dan proses penganggarannya mengikuti mekanisme yang berlaku.
Untuk Pembiayaan Desa memiliki hubungan dengan Alokasi Dana Desa, sehingga Pemerintah Daerah Kabupaten memberikan Alokasi Dana Desa kepada setiap Desa yang berada di wilayahnya. Hal ini tercantum pada Undang-Undang Nomor 6 Tahun 2014 tentang Desa yang menyebutkan bahwa keuangan desa adalah semua hak dan kewajiban Desa yang dapat dinilai dengan uang serta segala sesuatu berupa uang dan barang yang berhubungan dengan pelaksanaan hak dan kewajiban desa yang menimbulkan pendapatan, belanja, pembiayaan dan pengelolaan keuangan desa. Alokasi Dana Desa diberikan oleh pemerintah Pusat yang diperoleh dari dana perimbangan APBN yang diterima oleh Kabupaten/Kota dalam Anggaran Pendapatan dan Belanja Daerah (APBD) setelah dikurangi Dana Alokasi Khusus (DAK) sebesar 10\%. Dana tersebut kemudian dapat digunakan untuk membiayai penyelenggaraan, pemerintahan, pelaksanaan pembangunan, pembinaan kemasyarakatan, dan pemberdayaan masyarakat. Jumlah nominal yang akan diberikan kepada masingmasing desa akan berbeda tergantung dari georafis desa, jumlah penduduk, serta jumlah angka kematian. Alokasi dana sebesar $10 \%$ yang diterima oleh desa akan menyebabkan peningkatan terhadap pendapatan desa.

\section{E. METODE PENELITIAN}

Pendekatan dalam penelitian ini adalah pendekatan kuantitatif, karena penelitian ini disajikan dengan angka-angka. Hal ini sesuai dengan pendapat (Arikunto 2006: 12) yang mengemukakan penelitian kuantitatif adalah pendekatan penelitian yang banyak dituntut menguakan angka, mulai dari pengumpulan data, penafsiran terhadap data tersebut, serta penampilan hasilnya. Teknik pengumpulan data dalam penelitian ini yaitu Observasi merupakan teknik pengumpulan data, dimana peneliti melakukan pengamatan secara langsung ke objek penelitian untuk melihat dari dekat kegiatan yang dilakukan, Angket (kuesioner) adalah sejumlah pertanyaan tertulis yang digunakan untuk memperoleh informasi dari responden dalam arti laporan tentang pribadinya, atau hal-hal yang ia ketahui tentang akuntabilitas dan trasparansi pengelolan alokasi dana desa di desa Pao-pao Kabupaten Barru dan Dokumentasi adalah digunakan 
untuk memperoleh sejumlah data melalui bahan dokumen tertulis hal-hal yang sesuai dengan kebutuhan penelitian yang dilakukan.

\section{F. HASIL DAN PEMBAHASAN}

Pada penelitian ini akuntabilitas dan transparansi pengelolaan dana desa di desa pao-pao kecamatan tanete rilau kabupaten baruu digali melalui dimensidimensi yang diajukan Koppell (2005) Kelima dimensi tersebut adalah transparansi, liabilitas, kontrol, responsibilitas, dan responsivitas. Kelima kategori tersebut tidaklah mutually exclusive, yaitu organisasi bisa saja akuntabel dilihat dari beberapa pandangan. Meski demikian, transparansi dan liabilitas dipandang mendasari konsep akuntabilitas dalam segala bentuk manifestasinya.

\section{Dimensi Transparansi}

Transparansi adalah nilai utama dari akuntabilitas, dimana individu atau organisasi dikatakan akuntabel apabila ia mampu menjelaskan atau menilai tindakan atau aksinya. Dengan demikian, individu atau organisasi yang akuntabel tidak dapat menyembunyikan kesalahan atau menghindarkan dirinya dari sebuah penyelidikan. Transparansi merupakan instrumen yang paling penting untuk menilai kinerja organisasi, sebuah persyaratan kunci bagi semua dimensi akuntabilitas lainnya. Sebuah organisasi yang transparan menjamin akses kepada publik, pers, kelompok kepentingan, dan pihak lainnya yang memiliki kepentingan. Transparansi juga mensyaratkan kebenaran informasi kepada pihak-pihak yang berkepentingan dan publik. Pertanyaan penting untuk menilai akuntabilitas organisasi dari dimensi transparansi adalah: apakah organisasi mengungkapkan atau memberikan faktafakta terkait dengan kinerjanya.

\section{Tabel 1.}

Tanggapan Responden tentang Transparansi Pengelolaan Dana Alokasi Desa

\begin{tabular}{|l|c|c|}
\hline $\begin{array}{r}\text { Tanggapan } \\
\text { Responden }\end{array}$ & Frekuensi & $\begin{array}{c}\text { Persentasi } \\
\%\end{array}$ \\
\hline Baik & 31 & 56,4 \\
Cukup Baik & 18 & 30,9 \\
Kurang & 6 & 21,8 \\
Sangat Kurang & 0 & 0 \\
\hline Jumlah & 55 & 100 \\
\hline
\end{tabular}

Sumber : Data Primer, Tahun 2014

Berdasarkan tabel diatas dapat diketahui bahwa transpansi pengelolaan dana alokasi desa di desa pao-pao kabupaten barru termasuk dalam kategori baik. Hal ini dapat dilihat pada jumlah responden yang mengakui bahwa terjadi transparansi dalam pengelolaan dana alokasi desa terdapat $56,4 \%$ responden yang menganggap bahwa trasparansi pengelolaan dana alokasi desa terlaksana dengan transparan. Sementara terdapat responden yang menganggap transparansi pengelolaan dana alokasi desa di Desa Pao-Pao Kecamatan Tanete Rilau Kabupaten Barru terlaksana dengan cukup baik hal ini muncul dari peresentasi jumlah responden sejumlah $30,9 \%$ yang menganggap cukup, tetapi ada pula responden yang menganggap pengelolaan dana alokasi desa masih kurang transparan yakni $21,8 \%$ dan selanjutnya tidak ada responden yang mengatakan transparansi dalam pengelolaan dana alokasi desa ini sangat kurang baik.

Prinsip transparansi dapat dilihat dari arus informasi yang mudah diakses dari lokasi desa dan komunikasi yang baik oleh perangkat desa kepada masyarakat sekitar sehingga pengengelolaan dana alokasi desa dianggap transparan.

\section{Dimensi Liabilitas}

Pada dimensi liabilitas ini merupakan dimensi lain akuntabilitas. Beberapa konsepsi akuntabilitas mensyaratkan individu dan organisasi untuk dapat menghadapi segala konsekuensi yang melekat pada kinerja. Berdasarkan konsepsi ini, individu dan organisasi harus liable akan tindakan atau aksinya, memberikan ganjaran atau hukuman ketika terjadi pelanggaran, dan memberikan 
Vol. IV No. 2 Oktober 2014

reward ketika individu memberikan kesuksesan bagi organisasi. Pertanggungjawaban atas penyelewengan dana, ketidaktepatan alokasi risorsis, atau penyalahgunaan kewenangan atau otoritas. Sebaliknya, sistem remunerasi diberikan berdasarkan kinerja individu dan organisasi. Para pegawai publik menerima bonus dan kompensasi berdasarkan capaian kinerjanya.

Tabel 2.

Tanggapan Responden tentang Liabilitas Pengelolaan Dana Alokasi Desa fondasi transparansi dan liabilitas adalah control. Hal ini berlaku pula dalam sistem birokrasi, yang menekankan pola hubungan antara principal dan agent seperti yang telah diuraikan di awal tulisan ini. Konsepsi ini merupakan starting point untuk menganalisis akuntabilitas organisasi. Plausibilitas kontrol birokratis telah menjadi subyek pembicaraan dan perdebatan semenjak awal kelahiran ilmu administrasi publik. Wilson dan Goodnow menawarkan ide normatif tentang dikotomi politik dan administrasi. Dalam visinya, pejabat yang dipilih harus mampu mencapai segenap konsensus tujuan kebijakan publik, dan bersandarkan pada birokrat untuk mengimplementasikan kebijkan yang terpilih.

Sejalan dengan konsepsi ini, kontrol kepada birokrasi pemerintahan sebagai elemen penting dari akuntabilitas. Ia menegaskan bahwa birokrasi pemerintahan harus menjalankan kehendak publik yang terefleksikan melalui wakil-wakilnya dalam lembaga perwakilan (legislatif). Dalam pandangan kontrolbilitas, individu (birokrat) yang akuntabel dibatasi oleh perintah dari para principal. Namun, birokrat dan organisasi dibatasi oleh hukum, peraturan, dan normanorma. Inilah yang kemudian dilabelkan dengan istilah responsibilitas. Tentunya cakupan yang luas dari dimensi responsibilitas memberikan pemahaman yang variatif. Kepatuhan terhadap hukum merupakan sesuatu yang lebih preferable bagi birokrasi ketimbang kepatuhan kepada seorang principal.

yang menganggap kurang baik dari segi liabilitas sejumlah 21,8 \%.

Pengungkapan pelanggaran ataupun kinerja yang lemah tanpa adanya liabilitas merupakan cerminan dari lemahnya derajat akuntabilitas. Konsekuensi harus melekat erat dengan kinerja dalam bentuk reward, penambahan atau pengurangan kewenangan budget, meningkatkan atau mengurangi diskresi, atau meningkatkan atau mengurangi monitoring. Hal ini sejalan dengan prinsip liabilitas dalam akuntabilitas.

\section{Dimensi Kontrol}

Dimensi ketiga yang dibangun pada 
Tabel 3.

Tanggapan Responden tentang Dimensi Kontrol Pengelolaan Dana Alokasi Desa

\begin{tabular}{|l|c|c|}
\hline \multicolumn{1}{|c|}{$\begin{array}{c}\text { Tanggapan } \\
\text { Responden }\end{array}$} & Frekuensi & Persentasi \% \\
\hline Baik & 17 & 30,9 \\
Cukup Baik & 26 & 47,3 \\
Kurang & 8 & 14,5 \\
Sangat Kurang & 4 & 7,3 \\
\hline Jumlah & 55 & 100 \\
\hline
\end{tabular}

Sumber : Data Primer, 2014

Berdasarkan data di atas dapat diperoleh gambaran bahwa jumlah responden yang menganggap baik kontrol pengelolaan dana alokasi desa di Desa Pao-Pao Kecamatan Tanete Rilau Kabupaten Barru sejumlah 30,9 \% namun presentase control dalam pengelolaan dana alokasi desa ini menempatkan jumlah responden lebih banyak yang menganggap bahwa dana alokasi desa ini cukup baik dalam segi kontrol dalam pengelolaannya hal ini bisa dilihat dari jumlah responden yang menganggap cukup baik dari segi control yakni 47,3 \%. Terdapat juga responden yang menganggap bahwa control yang dilakukan dalam mengawal dana alokasi desa ini kurang baik hal ini ditandai dengan jumlah responden sejumlah 14,5 $\%$ menilai masih kurang dan 7,3 \% menganggap sangat kurang.

\section{Dimensi Responsibilitas}

Responsibilitas merupakan elemen kunci seperti yang dikemukakan oleh Friedrich dalam perdebatannya dengan Finer. Menurut Friedrich, birokrat yang akuntabel tidak harus mengikuti aturan atau perintah, tetapi harus menggunakan keahliannya yang dibatasi oleh standar profesional dan moral. Tidak mengherankan bila beberapa pengamat menilai bahwa standar profesional dapat menghindarkan kontrol melalui subtitusi

kepentingan-kepentingan profesional untuk public concerns. Kesemuanya itu pada akhirnya bermuara pada sebuah pertanyaan kunci akan dimensi responsibilitas, yaitu organisasi mengikuti segenap peraturan yang ada.

Tabel 4.

Tanggapan Responden tentang Dimensi Responsibilitas Pengelolaan Dana Alokasi Desa

\begin{tabular}{|l|c|c|}
\hline $\begin{array}{r}\text { Tanggapan } \\
\text { Responden }\end{array}$ & Frekuensi & Persentasi \% \\
\hline Baik & 21 & 38,2 \\
Cukup Baik & 16 & 29,1 \\
Kurang & 10 & 18,2 \\
Sangat Kurang & 8 & 14,5 \\
\hline Jumlah & 55 & 100 \\
\hline
\end{tabular}

Sumber : Data Primer, 2014

Berdasarkan data di atas dapat diperoleh gambaran bahwa responsibilitas yang dilihat dalam pengelolaan dana alokasi desa di desa pao-pao kecamatan tenete rilau kabupaten barru dianggap sejumlah responden berjalan dengan baik hal ini dilihat dari jumlah responden yakni 38,2 \% yang mengatakan baik pengelolaan dana alokasi desa ini dari segi responsibilitas. Sejumlah 29,1 \% menganggap bahwa responsibilitas dalam pengelolaan dana alokasi desa ini masih tergolong cukup baik. Kemudian terdapat sejumlah responden yang menganggap kurang yakni 18,2 \% dan terdapat $14,5 \%$ menganggap sangat kurang dari segi responsibilitas pengelolaan dana alokasi desa di Desa Pao-Pao Kecamatan Tanete Rilau Kabupaten Barru.

\section{Dimensi Responsivitas}

Responsivitas berkaitan dengan keinginan dari konstituen organisasi atau klien. Dengan demikian responsivitas cenderung menekankan pendekatan yang berorientasi pelanggan (customer-oriented approach) seperti yang disarankan dalam gerakan reinventing government. Setidaknya ada dua konsepsi responsivitas. Konsepsi pertama berfokus pada tuntutan dari pihak yang dilayani. Organisasi menetapkan sejumlah preferensi dari klien, mengumpulkan input, dan 
mengartikulasikan preferensi tersebut. Sedangkan konsepsi kedua lebih berfokus pada kebutuhan atau sasaran-sasaran substantif organisasi. Artinya, sebuah organisasi dikatakan akuntabel jika ia mampu mencapai sebuah sasaran substantif atau memenuhi kebutuhan tertentu.

Tabel 5.

Tanggapan Responden tentang Dimensi Responsivitas Pengelolaan Dana Alokasi Desa pengelolaan dana alokasi desa baik dari segi

liabilitas. Selanjutnya dari dimensi kontrol pengelolaan dana alokasi desa di Desa Pao-Pao Kecamatan Tanete Rilau Kabupaten Barru sejumlah 30,9 \% namun presentase control dalam pengelolaan dana alokasi desa ini menempatkan jumlah responden lebih banyak yang menganggap bahwa dana alokasi desa ini cukup baik dalam segi kontrol dalam pengelolaannya hal ini bisa dilihat dari jumlah responden yang menganggap cukup baik dari segi control yakni 47,3 \%. Hal ini mengartikan perlu dioptimalkan dari segi kontrol pengelolaan dana alokasi desa. Selanjutnya dari dimensi responsibilitas dan responsivitas pengelolaan dana alokasi desa di Desa PaoPao Kecamatan Tanete Rilau Kabupaten Barru dianggap berjalan dengan baik hal ini dapat dilihat dari jumlah responden yakni $38,2 \%$ yang mengatakan baik pengelolaan dana alokasi desa ini dari segi responsibilitas. Sementara terdapat $43,7 \quad \%$ yang menganggap bahwa responsivitas dalam pengelolaan dana alokasi desa berjalan dengan baik.
Berdasarkan hasil wawancara di atas dapat diketahui bahwa terdapat 43,7 $\%$ yang menganggap bahwa responsivitas dalam pengelolaan dana alokasi desa berjalan dengan baik selain itu terdapat $21,8 \%$ responden yang menganggap bahwa responsivitas dalam pengelolaan dana alokasi desa di Desa Pao-Pao Kecamatan Tanete Rilau Kabupaten Barru berjalan cukup baik. Kemudian terdapat $18,2 \%$ yang menganggap responsivitas dalam pengelolaan dana alokasi desa di desa pao-pao kecamatan tanete rilau ini berjalan kurang baik dan 16,3\% diantaranya berjalan sangat kurang.

Berangkat dari kelima dimensi yang menunjukkan akuntabilitas diketahui bahwa tingkat trasparansi pengelolaan dana alokasi desa di Desa Pao-Pao Kecamatan Tanete Rilau Kabupaten Barru dianggap berjalan dengan baik terdapat $56,4 \%$ responden yang mengganggap transparan. Selanjutnya pada dimensi liabilitas tergolong baik hal ini ditandai dengan jumlah informan yang menganggap baik ditandai dengan responden $\mathrm{s} \quad 47,3 \quad \%$ menganggap

\section{PENUTUP}

Sacara keseluruhan akuntabilitas pengelolaan dana alokasi desa di desa pao-pao kecamatan tanete rilau berjalan dengan baik dari keseluruhan dimensi yang dipaparkan, termasuk dalam dimensi transparansi yang menunjukkan pengelolaan dana alokasi desa berjalan trasparan hal ini terjadi karena informasi yang mudah diakses dari desa dan komunikasi yang baik oleh perangkat desa sehingga pengengelolaan dana alokasi desa dianggap transparan hanya dari dimensi control yang perlu dioptimal sementara dari dimensi reabiliy, responsibilitas dan responsivitas berjalan dengan baik.

Optimalisasi pengelolaan dana alokasi desa dari segi kontrol diperlukan karena dimensi ini yang dibangun pada fondasi transparansi dan liabilitas. Pengelolaan dana alokasi desa yang dianggap transparan perlu didukung oleh kontrol yang baik agar pelaksanaan akuntabilitas pengelolaan dana alokasi desa berjalan semakin efektif dan efesien secara administratif dan manfaatnya dapat dirasakan secara optimal oleh masyarakat desa. 


\section{DAFTAR PUSTAKA}

Arikunto, S. 2006. Prosedur Penelitian Suatu Pendekatan Praktik. Jakarta : Penerbit PT Rineka Cipta.

Krina, P. Loina. 2003. Indikator Dan Alat Ukur Prinsip Akuntabilitas, Transparansi dan Partisipasi. Jakarta : Sekretariat Good Governance BPPN.

Koppel, Jonathan. 2005. Pathologies of Accountabilty ICANN and the Challenge of "Multiple Accountability Disorder", Public Administration Review, January/February 2005, Vol. 65 No. 1.

Manggaukang, 2006. Akuntabilitas Pemerintahan Lokal Dalam Otonomi Daerah Studi Kasus di Pemerintahan Daerah Kabupaten
Sumbawa Provinsi NTB. Malang : Program Pascasarjana Brawijaya.

Rakhmat, 2009. Teori Administrasi dan Manajemen Publik. Banten : Pustaka Arif.

Shende, Suresh dan Tony, Bennet. 2004. Concept Paper 2: "Transparency and Accountability in Public Financial Administration", UN DESA.

Sedarmayanti, 2009. Reformasi Administrasi Publik, reformasi birokrasi dan kepemimpinan masa depan (mewujudkan pelayanan prima dan kepemerintahan yang baik). PT. Grafika Aditama : Bandung

Dokumen

Undang-undang Nomor 6 Tahun 2014 Tentang Desa 